Research Paper:

\title{
Professional Image Perceptions in First-year Nursing Students
}

\author{
Dilek Yılmaz ${ }^{1}$
}

1. Department of Nursing, Faculty of Health Sciences, Bursa Uludag University, Bursa, Turkey.

\begin{tabular}{|c|c|}
\hline $\begin{array}{l}\text { Use your device to scan } \\
\text { and read the article online }\end{array}$ & CFteation: Y1lmaz D 2019. Professional Image Percentions in First-vear Nursing Students. Journal of Client-Centered Nurs- \\
\hline 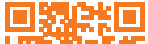 & ing Care, 5(3), pp. 141-146. https://doi.org/10.32598/JCCNC.5.3.141 \\
\hline trats & doli https://doi.org/10.32598/JCCNC.5.3.141 \\
\hline
\end{tabular}

(c) (1) (8)

Article info:

Received: 10 Jan 2019

Accepted: 23 Jun 2019

Published: 01 Aug 2019

Keywords:

Nursing, Nursing image, Professional image,

Student

\begin{abstract}
A B S T R A C T
Background: Determining the professional image perceptions of the first-year nursing students who have recently chosen the nursing profession is of great importance in delineating the profession profile. The present study aimed to determine the image perception of first-year nursing students and its related factors.

Methods: This descriptive cross-sectional research was conducted in the Fall semester of the 2019-2020 academic year. In total, 105 first-year nursing students were selected from the Nursing Department of the Faculty of Health Sciences of Bursa Uludağ University in Turkey. The study subjects were recruited randomly. A Student Identification Form and the Image Scale for the Nursing Profession were used as data collection tools. Mann-Whitney U and KruskalWallis tests were applied for analyzing the obtained data in SPSS.

Results: The Mean \pm SD score of the Image Scale for the Nursing Profession was achieved as $149.06 \pm 11.19$. Students who had willingly selected the nursing profession gained higher scores than those of other students in professional qualifications, education, professional status, and appearance scale sub-dimensions and total scale mean scores $(\mathrm{P}<0.05)$. In addition, the mean scores of the female students in the sub-dimensions of education, gender, and total scale were significantly higher than those of their male counterparts $(\mathrm{P}<0.05)$.
\end{abstract}

Conclusion: The nursing students indicated a good image perception of the nursing profession. Conducting a similar study is recommended for senior nursing students and staff nurses.

\footnotetext{
* Corresponding Author:

Dilek Ylmaz, PhD.

Address: Department of Nursing, Faculty of Health Sciences, Bursa Uludag University, Bursa, Turkey.

Tel: +90 (507) 3580330

E-mail:dilekk@uludag.edu.tr
} 


\section{Highlights}

- The nursing students' perception of the image of nursing is affected by the viewpoint of society towards the profession.

- The variables of gender and willingly selecting the profession could affect the professional image perception of nursing students.

-Willingly selecting the profession and liking the profession contribute to the formation of positive self-respect as well as professionalism.

\section{Plain Language Summary}

A professional image is the beliefs, ideas, and impressions of an individual about a profession. Nursing students could have positive and negative images of nursing. The obtained results suggested that nursing students had a good image perception of the nursing profession. Besides, gender and willingly selecting the profession could affect the professional image perception of nursing students.

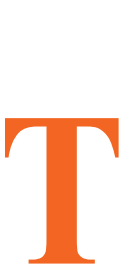

\section{Introduction}

he image of a profession is its evaluation by the society and the widespread acceptance of such evaluation (Dost \& Bahçecik 2015; Emiroğlu 2000). A professional image is the beliefs, ideas, and impressions of an individual about a profession (Eşer, Orkun \& Çetin 2017). Individuals' positive or negative impressions of a profession are shaped by their education as well as the status of that profession in society (Şimşek \& Alpar 2019). The prevailing status of a profession and the image of the professional group in the society are of great importance to the profession members (Eşer, Orkun \& Çetin 2017).

The image of nursing has become among the key factors affecting the nursing profession in its 100-150-year history in the world (Khorshid, Eşer \& Çınar 2005). The image of nursing is a factor affecting nurses' work performance, their intention to leave the job, and nurses' status, strength, and skills in developing healthcare (Fletcher 2007; Takase, Maude \& Manias 2006). Accordingly, the image of nursing has always been of great importance and concern (Emeghebo 2012; Kartal \& Kantek 2018). Nurses considering the profession as promising and providing services to the society who are concerned with what the profession is could be more effective in modifying the negative perceptions of society regarding the profession. Thus, nurses need to recognize the changes in perceptions associated with the views of nursing roles and their future (Dost \& Bahçecik 2015).

Additionally, to improve the nursing profession, there is a need for the members who love, have mastered the profession, and are qualified and have the responsibility in the practice of nursing care. Furthermore, this need is to be met by university students who are training to be future nurses (Korkmaz \& Görgülü 2010; Özkan et al. 2017).

According to the literature, nursing students' perceptions of the image of nursing are affected by the viewpoint of society towards the profession (İnce \& Khorshid 2015; Morris-Thompson et al. 2011). Studies on the same topic that included nursing students revealed that students have positive (Al Jarrah 2013; Andsoy et al. 2012; Karadağ, Pekmezci \& Sapçı 2015; Özdelikara, Boğa \& Çayan 2015) and negative (İnce \& Khorshıd 2015; Nazik \& Arslan 2014; Tan et al. 2007) images of nursing in society. Özkan et al. (2017) reported that nursing students had a moderate image perception of the nursing profession. Besides, Kaya and Dalgıç (2019) argued that the nursing image perception of nurses was at a low level.

The nursing profession has the potential to have a strong status as well as a desirable professional image among nurses (Sezer, Esenay \& Korkmaz. 2017). A positive image for nursing is critical in increasing nurses' job satisfaction as well as demonstrating professional successes and effectiveness (Hung et al. 2019; Kartal \& Kantek 2018). Thus, studies are required to investigate the professional image perceptions of nursing students as future nurses. In particular, determining the professional image perceptions of first-year nursing students, who have recently chosen the nursing profession, is essential in delineating the profession profile. The current study determined the image perception of first-year nursing students and their related factors. 


\section{Materials and Methods}

This was a descriptive and cross-sectional study. The research population consisted of the first-year students of the Nursing Department of the Health Sciences Faculty of Bursa Uludağ University, Turkey, in the Fall semester of the academic year 2019-2020. The research sample consisted of 105 students who voluntarily participated in the study. The inclusion criteria were being a firstyear nursing student and voluntarily joining the study. A simple random sampling technique was used to select the study subjects.

A Student Identification Form and the Image Scale for the Nursing Profession were used as data collection tools. Student Identification Form, prepared by the researchers, contained questions on age, gender, willingly selecting the nursing profession, and the existence of relatives who were nurses. The Image Scale for the Nursing Profession was developed and validated by Dost \& Bahçecik (2015). It is a five-point Likert-type scale and consists of 42 items.

The scale has 6 sub-dimensions: professional qualities, working conditions, gender, education, professional status, and society view. A high score on all sub-dimensions of the scale indicates high positive image perception in nurses. The obtainable total scale score ranges from 42 210 . The scale's reliability has been confirmed by Dost \& Bahçecik (2015), and its Cronbach's alpha coefficient was calculated as 0.88 . In the present study, the Cronbach's alpha coefficient was determined to be 0.80 .

The required data were collected in the classrooms before the beginning of classes. Prior to data collection, the researchers informed the students about the research purpose. It was ensured that the data collection process did not affect class time. It was explained to students that all of the data would be used for scientific study and that it would not affect their class marks. The data forms were completed by the students, and later collected back for evaluation.

The obtained data were analyzed in SPSS by frequency, percentage, mean, and standard deviation. The Kolmogorov-Smirnov test was used to determine the conformity of the scale score to normal distribution. Because the scale score did not indicate the normal distribution of the data, non-parametric tests were used; the Mann-Whitney U test for two independent variables, and the Kruskal-Wallis test for more than two independent variables.

\section{Results}

In total, $82.9 \%$ of the participating students were female, with a Mean \pm SD age of $18.90 \pm 1.88$ years. Additionally, $76.2 \%$ of the samples had selected the nursing profession willingly, and $41 \%$ had relatives who were working as nurses.

The students' Mean $\pm \mathrm{SD}$ score on the Image Scale for the Nursing Profession was calculated to be $149.06 \pm 11.19$. The subjects' sub-dimensions scores of the scale were $45.58 \pm 3.76$ on professional quality, $26.87 \pm 2.96$ on working conditions, $29.06 \pm 4.89$ on gender, $19.60 \pm 2.29$ on education, $16.36 \pm 4.69$ on professional status, and $11.57 \pm 2.83$ on society view (Table 1 )

Table 2 illustrates a comparison of the students' Mean \pm SD scores on the Image Scale for the Nursing Profession and its sub-dimensions according to their descriptive characteristics. The students who had willingly chosen the profession had significantly higher mean

Table 1. Distribution of students' scores on the image scale for the nursing profession and its sub-dimensions ( $\mathrm{N}=105)$

\begin{tabular}{|c|c|c|}
\hline Scale and Sub-dimensions & Mean士SD & Minimum-Maximum Score \\
\hline Professional quality & $45.58 \pm 3.76$ & $33-51$ \\
\hline Working conditions & $26.87 \pm 2.96$ & $19-37$ \\
\hline Gender & $29.06 \pm 4.89$ & $12-44$ \\
\hline Education & $19.60 \pm 2.29$ & $9-25$ \\
\hline Professional status & $16.36 \pm 4.69$ & $5-25$ \\
\hline Society view & $11.57 \pm 2.83$ & $5-15$ \\
\hline Total scale score & $149.06 \pm 11.19$ & $118-183$ \\
\hline
\end{tabular}


Table 2. Comparing students' scores on the image scale for the nursing profession and its sub-dimensions by their descriptive characteristics $(\mathrm{N}=105)$

\begin{tabular}{|c|c|c|c|c|c|c|c|c|}
\hline & & & & & Mean $\pm S$ & & & \\
\hline & ables & $\begin{array}{c}\text { Professional } \\
\text { Quality }\end{array}$ & $\begin{array}{l}\text { Working } \\
\text { Conditions }\end{array}$ & Gender & Education & $\begin{array}{l}\text { Professional } \\
\text { Status }\end{array}$ & $\begin{array}{l}\text { Outside } \\
\text { View }\end{array}$ & $\begin{array}{l}\text { Scale Total } \\
\text { Score }\end{array}$ \\
\hline & Female & $45.63 \pm 3.61$ & $27.08 \pm 2.83$ & $29.79 \pm 4.52$ & $19.95 \pm 2.17$ & $16.62 \pm 4.44$ & $11.49 \pm 2.86$ & $150.57 \pm 10.39$ \\
\hline 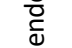 & Male & $45.33 \pm 4.52$ & $25.88 \pm 3.42$ & $25.55 \pm 5.26$ & $17.94 \pm 2.18$ & $15.11 \pm 5.73$ & $11.94 \pm 2.71$ & $141.77 \pm 12.31$ \\
\hline & $\mathrm{P}^{*}$ & 0.990 & 0.441 & 0.001 & 0.000 & 0.340 & 0.647 & 0.10 \\
\hline مه & Yes & $46.63 \pm 3.15$ & $27.00 \pm 3.03$ & $29.31 \pm 5.31$ & $20.01 \pm 2.08$ & $16.81 \pm 4.83$ & $11.95 \pm 2.78$ & $151.72 \pm 10.44$ \\
\hline 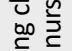 & No & $42.20 \pm 3.59$ & $26.48 \pm 2.74$ & $28.28 \pm 3.20$ & $18.32 \pm 2.49$ & $14.92 \pm 3.97$ & $10.36 \pm 2.69$ & $140.56 \pm 9.22$ \\
\hline $\bar{\xi}^{0}$ & $\mathrm{P}^{*}$ & 0.000 & 0.462 & 0.149 & 0.001 & 0.040 & 0.018 & 0.000 \\
\hline & & $45.46 \pm 3.91$ & & & & & & \\
\hline 訔 & Yes & $45.66 \pm 3.68$ & $26.27 \pm 2.60$ & $28.02 \pm 4.47$ & $19.67 \pm 1.65$ & $16.53 \pm 4.52$ & $11.41 \pm 2.83$ & $147.39 \pm 10.64$ \\
\hline 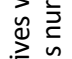 & No & 0873 & $27.29 \pm 3.13$ & $29.79 \pm 5.08$ & $19.56 \pm 2.66$ & $16.24 \pm 4.85$ & $11.67 \pm 2.85$ & $150.22 \pm 11.50$ \\
\hline$\frac{\pi}{2}$ & $\mathrm{P}^{*}$ & & 0.212 & 0.53 & 0.897 & 0.948 & 0.698 & 0.165 \\
\hline
\end{tabular}

scores on the sub-dimensions of professional quality, education, professional status, outside view, and on the total scale $(\mathrm{P}<0.05)$. In addition, the Mean \pm SD scores of female students on the sub-dimensions of education and gender and the total scale were calculated to be significantly higher than those of their male counterparts $(\mathrm{P}<0.05)$. On the other hand, no significant difference was found between the sub-dimension and scale total Mean \pm SD scores and whether the students had relatives working as nurses $(\mathrm{P}>0.05)$ (Table 2$)$.

\section{Discussion}

Fealy (2004) stated that the image of nursing could identify the profession's limitations and reflect the value of a professional nurse. The image of nursing affects the quantity and quality of those making decisions for nursing, as a profession (Özmen \& Çetinkaya 2016). Determining the professional image perceptions of first-year nursing students who have recently chosen the nursing profession is essential for determining the professional profile. According to the present study findings, students' image perception regarding the nursing profession was at a good level. A study reported that the perceptions of nursing students in their profession were generally positive (Al Jarrah, 2013). Cook, Gilmer \& Bess (2003) investigated the perceptions of nursing students at the beginning of their nursing education. They concluded that the students had very idealistic views of the profession, focusing on concepts, such as kindness and compassion.
Other related studies also found that the students' images of nursing were at a good level (Andsoy et al. 2012; Karadağ, Pekmezci \& Sapç1 2015; Özdelikara, Boğa \& Çayan 2015). These conclusions are similar to those of our study. However, in a study by Özkan et al. (2017), the nursing students' image perceptions of the nursing profession were at a moderate level. Furthermore, Kaya and Dalgıç (2019) suggested a low level of students' image perceptions of nursing. Such data discrepancy may arise from the demographic and cultural differences of the study samples and the history of nursing in different countries.

Nurses must possess certain characteristics in order to carry out their professional roles, duties, and responsibilities. These include such qualities as having scientific knowledge, being patient in guiding patients, and communicating openly (Kumcağı et al. 2011; Özkan et al. 2017). Moreover, the investigated students achieved the highest mean scores on the sub-dimension of professional quality. Similar results were reported by Özkan et al. (2017) and Andsoy et al. (2012).

A promising finding was the high score of professional quality sub-dimension in nursing students. This is because the nursing profession depends on science; has high creativity and multi-directional communication; requires devotion and patience, and carries social responsibilities (Sezer, Esenay \& Korkmaz. 2017). The image of the profession is related to the value accorded, and the respect felt for the profession by those who practice it. It 
is of particular importance for the status of the nursing profession as well as professional development that new nurses have professional qualities.

According to the collected data, students who had willingly chosen the nursing profession obtained significantly higher mean scores on the sub-dimensions of professional quality, education, professional status, social view, and the total scale, compared to others. Choosing the profession willingly and loving the profession could contribute to the formation of positive self-respect and professionalism. This is because students will be more successful in academic and professional life, could delightedly practice the profession, internalize the profession, and improve their professional knowledge and skills (Pınar et al. 2013). Therefore, satisfaction with the profession increases professionalism, i.e. positively reflected in professional image perception.

The nursing profession may alter through sociocultural, scientific, and technological developments (Karamanoğlu et al. 2009). Furthermore, it is affected by a person's knowledge, competence, communication, gender, education, working conditions, professional qualities, status, and social view (Fletcher 2007; Sezer, Esenay \& Korkmaz 2017; Tzeng 2006); gender is the most significant factor of all, because the nursing profession, given its caregiving role, has long been considered by society as a females' profession. Besides, the genderdiscriminated roles in society are reflected in their professional status. We observed that female students had a more positive image perception of nursing than males. As a result, the later addition of males to the nursing profession in Turkey and the perception that nursing was a profession for women could have a more positive effect on the nursing image perception of female students than that of males. Furthermore, according to some studies, gender does not affect the image perception of nursing (Özkan et al. 2017; Sezer, Esenay \& Korkmaz 2017). These differences between studies are interpreted as arising from dependent variables relating to the samples included in the studies.

Özkan et al. determined the professional image perceptions of nursing students. They found that having a relative who was working as a nurse positively affected students' image perceptions. In the same study, it was reported that having a relative who worked as a nurse helped individuals to recognize the nursing profession more clearly and realistically and that this positively shaped their professional image perception (Özkan et al. 2017). Other studies documented the professional image perceptions of those in the profession who knew members of a health team were positive (Çelik et al. 2013; Sarıkaya \& Khorshid 2009). The present study revealed that students' image perceptions were not affected by having a relative working as a nurse. Thus, the present study conclusion differs from that of the literature. Conducting the study at only one center, restricting the samples to first-year nursing students, and the self-report nature of the questionnaire were among the current study limitations.

To improve the image of nursing, students' awareness of the importance of professional image should be promoted. To develop a more positive professional image in students, it is recommended that academic and clinical nurses serve as role models and guiders. In addition, it is suggested that the study be repeated in broader groups. Conducting a similar study is also recommended for senior nursing students and staff nurses.

\section{Ethical Considerations}

\section{Compliance with ethical guidelines}

The necessary written permission for the research was obtained from the Clinical Research Ethics Committee of the Medical Faculty of Bursa Uludağ University (Code: 2019-14/6), and permission was obtained from the owners to use the Image Scale for the Nursing Profession. Besides, an informed consent form was obtained from the students who voluntarily participated in the study after providing explanations on the study purposes.

\section{Funding}

This research received no specific grant from funding agencies in the public, commercial, or not-for-profit sectors.

\section{References}

Al Jarrah, I. A. T., 2013. Associate nursing students' perceptions toward nursing profession in Jordan. European Scientific Journal, 9(6), pp. 147-66.

Andsoy, I., Güngör, T. \& Bayburtoğlu, T., 2012. Karabuk university health school students' thoughts about the future of their profession and the causes of preferring nursing. $\mathrm{Ba}$ likesir Health Sciences Journal, 1(1), pp. 124-30. [DOI:10.5505/ bsbd.2012.87597]

Cook, T., Gilmer, M. \& Bess, C., 2003. Beginning students' definitions of nursing: an inductive framework of professional identity. Journal of Nursing Education, 42(7), pp. 311-7. 
Çelik, A. S., et al. 2013. [Determination of the image of nursing profession in community (Turkish)]. Florence Nightingale Journal of Nursing, 21(3), pp. 147-53.

Dost, A. \& Bahçecik, A. N., 2015. Developing a scale for the image of nursing profession. Journal of Academic Research in Nursing, 1(2), pp. 51-9. [DOI:10.5222/jaren.2015.051]

Emeghebo, L., 2012. The image of nursing as perceived by nurses. Nurse Education Today, 32(6), pp. 49-53. [DOI:10.1016/j. nedt.2011.10.015] [PMID]

Emiroğlu, N., 2000. [Nursing image of health personnel and society (Turkish)]. Journal of Nursing Research, 1(1), pp. 9-18.

Eşer, İ., Orkun, N. \& Çetin, P., 2017. [The image of nursing and a series of advertisements published in the 1950s (Turkish)] Dokuz Eylul University Faculty of Nursing Electronics Journal, 10(4), pp. 275-8.

Fealy, G. M., 2004. The good nurse: visions and values in images of the nurse. Journal of Advanced Nursing, 46(6), pp. 649-56. [DOI:10.1111/j.1365-2648.2004.03056.x] [PMID]

Fletcher, K., 2007. Image: Changing how women nurses think about themselves: Literature review. Journal of Advanced Nursing, 58(3), pp. 207-15. [DOI:10.1111/j.1365-2648.2007.04285.x] [PMID]

Hung, C. A., et al. 2019. The effect of gender-friendliness barriers on perceived image in nursing and caring behaviour among male nursing students. Journal of Clinical Nursing, 28(9-10), pp. 1465-72. [DOI:10.1111/jocn.14693] [PMID]

İnce, S. \& Khorshid, L., 2015. Determination of factors affecting career choices of nursing students. Journal of Anatolia Nursing and Health Sciences, 18(3), pp. 163-71. [DOI:10.17049/ ahsbd.08012]

Karadağ, G., Pekmezci, S. \& Sapçı, E., 2015. Thought and expectations of nursing students through education and professional. Gaziantep Medical Journal, 25(1), pp. 26-31. [DOI:10.5455/ GMJ-30-168148]

Karamanoğlu, Y. A., Gök, Ö. F. \& Tuğcu, A., 2009. [Evaluation of surgical ward nurses professionalism in their work, in Denizli (Turkish)]. Firat Medical Journal, 14(1), pp. 12-7.

Kartal, H. \& Kantek, F., 2018. Examination of psychometric characteristics of the nursing image scale among nurse manegers. Medical Journal of Baktrkoy, 14, pp. 190-7. [DOI:10.5350/BTDMJB.20170322030251]

Kaya, A. \& Dalgıç, A. İ., 2019. Relationship between student nurses' perception of nurses, nursing images and effective factors: A crosssectional study. Paper Presented at the $2^{\text {nd }}$ International Health Sciences and Life Congress, Burdur, Turkey, 24-27 April 2019.

Khorshid, L., Eşer, İ. \& Çınar, Ş., 2005. [Students' views on nursing image in society (Turkish)]. Journal of Ege University Nursing Faculty, 21, pp. 581-8.

Korkmaz, F. \& Görgülü, S., 2010. [Viewpoint of nurses on nursing in respect to professionalism criteria (Turkish)]. Hacettepe University Faculty of Health Sciences Nursing Journal, 17(1), pp. $1-17$.

Kumcağız, H., et al. 2011. [Communication skills of nurses: Samsun sample (Turkish)]. Dicle Medical Journal, 38(1), pp. 49-56.
Morris- Thompson, T., et al. 2011. Diversity, fulfilment and privilege: The image of nursing. Journal of Nursing Management, 19(5), pp. 683-92. [DOI:10.1111/j.1365-2834.2011.01268.x] [PMID]

Nazik, E. \& Arslan, S., 2014. The future of nursing: The hopes of students. Bozok Medical Journal, 4(1), pp. 33-40. [DOI:10.16919/ btd.03702]

Özdelikara, A., Boğa, N. M \& Çayan, N., 2015. [Nursing image from the view of nursing students and other section students (Turkish)]. Journal of Duzce University Health Sciences Institute, 5(2), 1-5.

Özkan, Z. K, et al. 2017. [Professional image perception of a group of nursing students (Turkish)]. Journal of Research and Development in Nursing, 19(1), pp. 38-47.

Özmen, D. \& Çetinkaya, A., 2016. [A qualitative study of professional perceptions of senior nursing students (Turkish)]. Journal of Research and Development in Nursing, 18(1), pp. 40-52.

Pınar, Ş. E., et al. 2013. [Analysis of occupational professionalism of midwifery students and affecting factors (Turkish)] Firat Health Services Journal, 8(23), pp. 19-37.

Sarıkaya, T. \& Khorshid, L., 2009. [The investigatıon of the factors that affect university students' profession choice: University students' profession choice (Turkish)]. The Journal of Turkish Educational Sciences, 7(2), pp. 393-423.

Sezer, T. A., Esenay, F. I. \& Korkmaz, G., 2017. [Occupational image of pediatric nurses: Professional or traditional (Turkish)]. Journal of Research and Development in Nursing, 19(3), pp. 45-54.

Şimşek, A. K. \& Alpar, Ş. ., 2019. [Image perception of the society for nursing profession: Systematic review (Turkish)]. Sakarya University Journal of Holistic Health, 2(1), pp. 32-46.

Takase, M., Maude, P. \& Manias, E. 2006. Impact of the perceived public image of nursing on nurses' work behaviour. Journal of Advanced Nursing, 53(3), pp. 333-43. [DOI:10.1111/ j.1365-2648.2006.03729.x] [PMID]

Tan, M., et al. 2007. [Point of view on nursing of university students (Turkish)]. Journal of Anatolia Nursing and Health Sciences, 10(1), pp. 22-9.

Tzeng. H. M., 2006. Testing a conceptual model of the image of nursing in Taiwan. International Journal of Nursing Studies, 43(6), pp. 755-65. [DOI:10.1016/j.ijnurstu.2005.10.004] [PMID] 